\title{
SISTEM INFORMASI PERSEDIAAN BARANG DAGANG MENGGUNAKAN METODE PERHITUNGAN PERPERTUAL DAN METODE FIRST IN FIRST OUT PADA CV. HARAPAN SUKSES MANDIRI, TANJUNGPINANG
}

\author{
Dwi Nurul Huda ${ }^{1}$, Vidani $^{2}$, Nurul Hilda Syani P. ${ }^{3}$ \\ 1,2,3 Jurusan Sistem Informasi STT Indonesia Tanjungpinang \\ Jln. Pompa Air No. 28 Tanjungpinang Kepulauan Riau Indonesia \\ 1dwi.nurulhuda@gmail.com, 2vidanii_thiink@yahoo.co.id, 33urulhidaasp14@gmail.com
}

\begin{abstract}
Intisari- Proses pengolahan data pembelian, penjualan, stok barang maupun hutang dan piutang pada CV. Harapan Sukses Mandiri masih menggunakan cara manual. Maka pengolahan data pada CV. Harapan Sukses Mandiri belum bisa dikatakan efektif dan cenderung memakan waktu yang lebih lama, tentunya masih terdapat kemungkinan terjadinya kesalahaan selama proses pencatatan. Untuk menanggapi masalah tersebut, akan dirancang suatu sistem informasi persediaan barang menggunakan metode perhitungan perpetual dan metode First In First Out yang baru untuk memberikan suatu alternatif bagi perusahaan dalam mengolah datanya. Perangkat lunak yang digunakan untuk membangun sistem informasi persediaan barang menggunakan metode perhitungan perpetual dan metode First In First Out pada CV. Harapan Sukses Mandiri adalah Visual Studio 2010 dengan database MySQL. Berdasarkan pengujian yang dilakukan sistem dibangun dapat menyelesaikan masalah yang ada pada sistem pengolahan data yang lama.

Kata Kunci : Sistem, Informasi, Pembelian, Penjualan, Hutang, Piutang.
\end{abstract}

Abstract-The process of data processing purchases, sales, stocks of goods and payables and receivables at CV. Harapan Suskses Mandiri still using manual way and data processed at CV. Harapan Suskses Mandiri at this time is the stock data, purchase data, sales data, data payable and data receivable. Related to the processing of data that is still processed manually, the way data processing on CV. Harapan Suskses Mandiri can't be said to be effective and tend to take a longer time, of course there is still the possibility of misconduct during the process of recording. To respond to the problem, we will design a inventory information system using the method of calculation perpetual and new fifo method to provide an alternative for companies in processing the data. Data collection techniques used include observation, interviews, and literature study. For data analysis technique used waterfall method and for structured analysis method that is ERD (Entity Relationship Diagram to describe data model and DFD (Data Flow Diagram) in describing functional model. The software used to build inventory information systems using the method of calculation perpetual and fifo method on CV. Harapan Suskes Mandiri is Visual Studio 2010 with MySQL database. Based on the test conducted the system built to solve existing problems in the old data processing system. Keywords : System, Information, Purchase, Sales, Debt, Accounts Receivable.

\section{Pendahuluan}

CV. Harapan Suskes Mandiri merupakan suatu perusahaan yang bergerak dalam bidang distributor yang mendistribusi makanan ringan kepada konsumen. Konsumen yang dimaksudkan seperti toko-toko retail maupun toko-toko yang ada di pasar tradisional. Sistem penjualan yang diterapkan pada CV. Harapan Sukses Mandiri yaitu dengan memasarkan produk ke konsumen dengan melalui salesman. Sebagai perusahaan distributor maka kegiatan utama dari perusahaan adalah penerimaan dan pengeluaran barang.

Saat ini CV. Harapan Sukses Mandiri menerapkan proses pemesanan barang masih dilakukan secara manual yaitu dengan cara menulis melalui catatan-catatan daftar pemesanan barang, sehingga pencatatan yang terjadi akan sangat menghabiskan waktu dan tenaga bagi bagian yang mengerjakannya. Selain itu, cara tersebut dapat memungkinkan terjadinya penyimpangan - penyimpangan yang bisa dilakukan oleh karyawan yang tidak bertanggung jawab, seperti barang yang dicatat tidak sesuai dengan barang yang ada dilapangan, atau catatan laporan persediaan barang bisa hilang atau rusak.
Oleh karena itu, maka penulis mengambil judul "Sistem Informasi Persediaan Barang Dagang Menggunakan Metode Perhitungan Perpetual dan Metode First In First Out Pada CV. Harapan Sukses Mandiri, Tanjungpinang”.

\section{Metodologi Penelitian}

Metode pengembangan dalam pembuatan perangkat lunak ini menggunakan model SDLC (System Development Life Cycles) yang meliputi beberapa proses seperti Perencanaan, Analisis, Perancangan, Implementasi, Pengujian, Pemeliharaan. Adapun model pengembangan dalam pembuatan perangkat lunak menurut Adi Nugroho yang dapat dilihat dari gambar di bawah ini: 


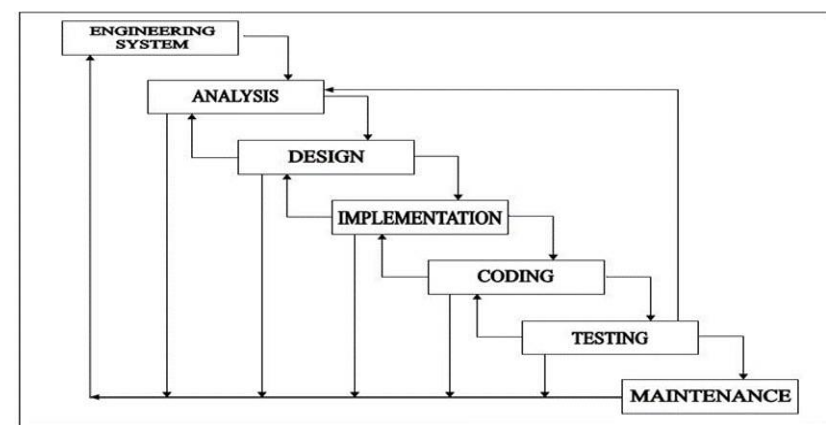

Gambar 1. Metode Waterfall [2]

Keterangan :

1. Perencanaan (Engineering System) adalah Tahapan mengenai masalah perangkat lunak, perangkat keras dan sumber daya manusia.

2. Analisis (Analysis) adalah Melakukan analisis sistem dengan mencari penyebab-penyebab masalah yang timbul sabagai dasar perancangan sistem baru.

3. Perancangan (Design) adalah Proses mengubah kebutuhan-kebutuhan menjadi bentuk karakteristik yang dimulai dengan penulisan program design tadi harus diubah menjadi bentuk yang dimengerti sistem.

4. Implementasi (Implementation) adalah Tahap penerjemahan desain kedalam bahasa pemrograman yang sesuai dengan kebutuhan.

5. Pengkodean (Coding) adalah desain yang harus diubah bentuknya menjadi bentuk yang dimengerti oleh komputer. Tahanpan ini yang secara teknik akan dikerjakan oleh sistem.

6. Pengujian (Testing) adalah Tahap pengujian perangkat lunak yang telah dikembangkan untuk cover kesalahan-kesalahan dan menjamin bahwa mesukan sesuia dengan hasil yang ditentukan.

7. Pemeliharaan (Maintenance) adalah Tahap perawatan sistem yang telah dikembangkan seperti perawatan perangkat lunak, perangkat keras dan media lain yang berhubungan dengan komputer. Pada tahap ini segala kemungkinan mengenai kekurangan perangkat lunak baik berupa kesalahan atau hal-hal yang ditambahkan kedalam perangkat lunak.

\section{LANDASAN TEORI}

\section{A. Pengertian Sistem}

Sistem menurut Mulyadi adalah sekelompok unsur yang erat berhubungan satu dengan yang lainnya, yang berfungsi bersama-sama untuk mencapai tujuan tertentu [5] dan menurut Murdick dan Ross mendefinisikan sistem sebagai seperangkat elemen yang digabungkan satu dengan lainnya untuk suatu tujuan bersama.[6] Selanjutnya menurut L James Havery Sistem merupakan suatu kesatuan yang dinamis dalam melakukan pergerakan yang terarah pada pencapaian tujuan integral dengan bantuan komponen atau bagian-bagian yang harmonis secara utuh saling berhubungan dan mendukung keberhasilannya.[7]

\section{B. Pengertian Informasi}

Informasi merupakan hasil dari pengolahan data, akan tetapi tidak semua hasil dari pengolahan tersebut bisa menjadi informasi, hasil pengolahan data yang tidak memberikan makna atau arti serta tidak bermanfaat bagi seseorang bukanlah merupakan informasi bagi orang tersebut.

Menurut Sutarman informasi adalah sekumpulan fakta (data) yang diorganisasikan dengan cara tertentu, sehingga mereka mempunyai arti bagi si penerima.

\section{Pengertian Pencatatan Perpertual}

Sistem pencatatan metode perpetual disebut juga metode buku adalah sistem dimana setiap persediaan yang masuk dan keluar dicatat di pembukuan. Setiap jenis barang dibuatkan kartu persediaan dan di dalam pembukuan dibuatkan rekening pembantu persediaan. Rincian dalam buku pembantu bisa diawasi dari rekening kontrol persediaan barang dalam buku besar. Rekening yang digunakan untuk mencatat persediaan ini terdiri dari beberapa kolom yang dapat dipakai untuk mencatat pembelian, penjualan dan saldo persediaan. Setiap perubahan dalam persediaan diikuti dengan pencatatan dalam rekening persediaan sehingga jumlah persediaan sewaktu-waktu dapat diketahui dengan melihat kolom saldo dalam rekening persediaan. Setiap kolom dirinci lagi untuk kuantitas dan harga perolehnya.[4]

\section{Metode Perhitungan First In First Out (FIFO)}

Metode penentuan harga pokok ini mengasumsikan bahwa biaya akan mengalir seperti sesuatu barisan tertentu. Artinya barang yang pertama masuk diasumsikan akan dijual pertama kali pula dan barang yang yang masuk terakhir akan dijual terakhir pula. Hingga persediaan akhir akan ditentukan dengan menggunakan harga barang yang terakhir masuk ke perusahaan.

Penggunaaan Metode FIFO akan mengakibatkan nilai harga pokok penjualan cenderung lebih rendah dibandingkan dengan menggunakan metode lainnya. Sebaliknya nilai persediaan

akhir ini dimiliki perusahaan akan menjadi lebih tinggi dibandingkan dengan menggunakan metode lainnya.[3]

\section{HASIL DAN PEMBAHASAN}

Pada tahap perancangan aplikasi ini terdiri dari analisis prosedur yang diusulkam, Diagram Konteks, Data Flow Diagram (DFD), Entity Relationship Diagram (ERD), Struktur File, Struktur Menu, Struktur Program dan Perancangan Input dan Output Program.

\section{A. ANALISIS SISTEM}

1) Prosedur Pembelian yang sedang berjalan

- Bagian kepala gudang akan memberikan daftar data barang yang akan dipesan kepada bagian admin.

- Bagian admin membuat data pemesanan barang dan diberikan kepada pimpinan untuk persetujuan jika tidak setuju, maka ditolak olehh pimpinan. Jika setuju, maka data pemesanan akan diberikan kepada supplier oleh admin.

- Data pemesanan barang yang diterima oleh supplier akan membuat faktur pembelian beserta 
barang yang dipesan diberikan kepada bagian kepala gudang.

- Setelah faktur pembelian beserta barang diterima oleh bagian kepala gudang, maka bagian kepala gudang akan mengecek barang pesanan. Jika tidak sesuai dengan yang dipesan, maka proses pembelian dibatalkan. Jika sesuai, maka bagian kepala gudang akan membuat data transaksi kedalam buku stok barang dan membuat laporan stok barang sebanyak 2(dua) rangkap. 1(satu) diberikan kepada pimpinan dan 1(satu) untuk arsipan.

- Faktur pembelian akan diberikan kepada bagian admin oleh kepala gudang. Setelah menerima faktur pembelian, maka bagian admin akan membuat laporan pembelian sebanyak 2(dua) rangkap. 1(satu) diberikan kepada pimpinan dan 1(satu) untuk arsipan.

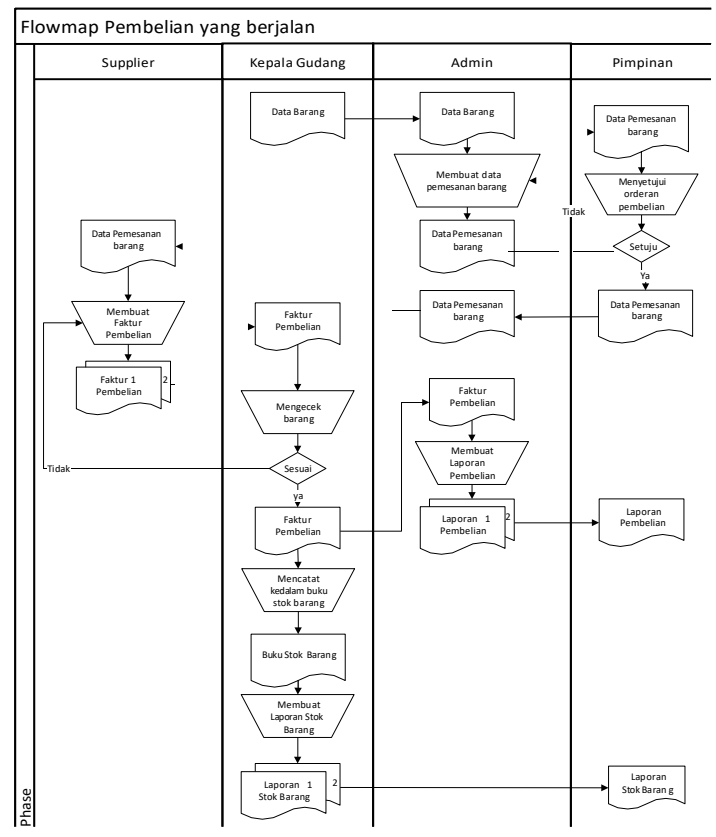

Gambar 2. Flowmap Pembelian yang sedang berjalan

\section{2) Prosedur PenJualan yang SEDANG BERJALAN}

- Konsumen memberikan data barang yang akan dipesan kepada sales yang datang ke toko.

- Setelah sales menerima data barang dari konsumen, maka sales akan berikan kepada kepala gudang.

- Setelah diterima oleh kepala gudang data barang tersebut maka, Kepala gudang akan mencari barang yang dipesan. Jika tidak ada, maka proses penjualan barang dibatalkan. Jika ada, maka kepala gudang akan menyiapkan barang-barang yang dipesankan oleh konsumen dan daftar barang tersebut akan diberikan kepada Admin untuk melakukan penjualan.

- Setelah terima data penjualan dari kepala gudang, maka admin akan membuat faktur penjualan dan surat jalan. Faktur penjualan dan surat jalan dalam
2 (dua) rangkap 1(satu) rangkap diberikan kepada konsumen beserta barang pesanan untuk tanda terima barang dan 1(satu) rangkap untuk arsipan penjualan bagian admin.

- Bagian admin akan membuat laporan penjualan sebanyak 2(dua)rangkap, 1(satu)rangkap untuk pimpinan dan 1(satu) rangkap untuk arsipan admin.

- Bagian Kepala Gudang akan membuat data barang kedalam buku stok barang dan membuat laporan stok barang sebanyak 2(dua)rangkap, 1(satu)rangkap untuk pimpinan dan 1(satu) rangkap untuk arsipan kepala gudang.

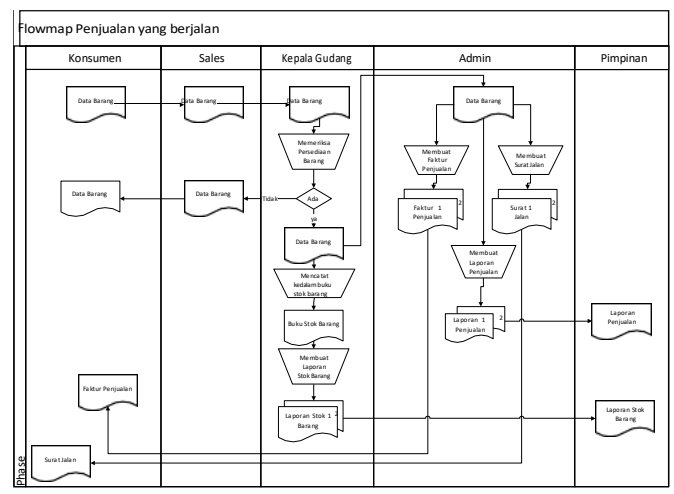

Gambar 3. Flowmap Penjualan yang sedang berjalan

\section{B. PERANCANGAN SISTEM}

1) Prosedur Pembelian yang diusulkan:

- Bagian admin membuat data pemesanan barang dan diberikan kepada pimpinan untuk persetujuan jika tidak setuju, maka ditolak oleh pimpinan. Jika setuju, maka data pemesanan akan diberikan kepada supplier oleh admin

- Data pemesanan barang yang diterima oleh supplier akan membuat faktur pembelian beserta barang yang dipesan diberikan kepada bagian kepala gudang.

- $\quad$ Setelah faktur pembelian beserta barang diterima oleh bagian kepala gudang, maka akan mengecek barang pesanan. Jika tidak sesuai dengan yang dipesan, maka proses pembelian dibatalkan. Jika sesuai, maka bagian admin akan menginput data pembelian kedalam database.

- Dari hasil penginputan tersbut, bagian admin dan mencetak laporan stok barang kepada pimpinan. dan laporan pembelian untuk diserahkan kepada kepala gudang dan pimpinan. 


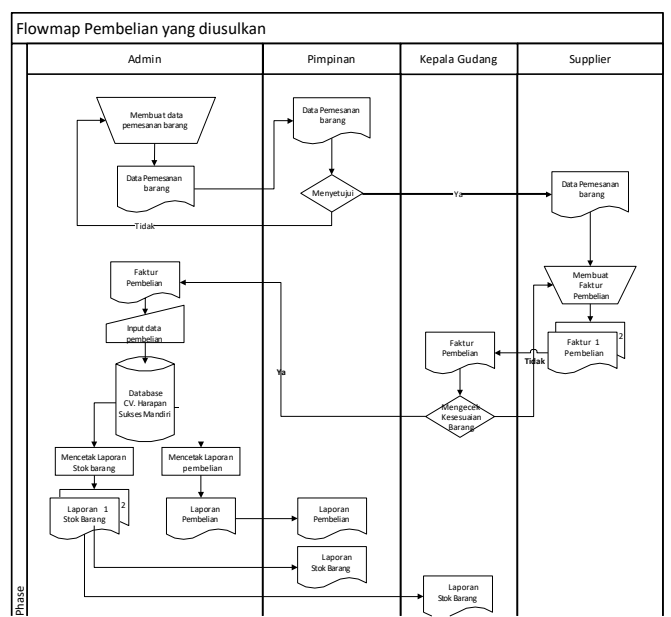

Gambar 4. Flowmap Pembelian yang diusulkan

2) Prosedur Penjualan yang diusulkan

- Konsumen memberikan data barang yang akan dipesan kepada sales yang datang ke toko.

- Setelah sales menerima data barang dari konsumen, maka sales akan berikan kepada kepala gudang.

- Setelah diterima oleh kepala gudang data barang tersebut maka, kepala gudang akan mencari barang yang dipesan. Jika tidak ada, maka proses penjualan barang dibatalkan. Jika ada, maka kepala gudang akan menyiapkan barang-barang yang dipesankan oleh konsumen.

- Setelah itu, bagian admin akan menginput data transaksi penjualan kedalam database dan mencetak nota penjualan kepada konsumen.

- Dari hasil penginputan data tersebut, bagian admin akan mencetak rincian penjualan dan laporan stok barang kepada kepala gudang. Sedangkan laporan stok barang dan laporan penjualan diserahkan kepada pimpinan.

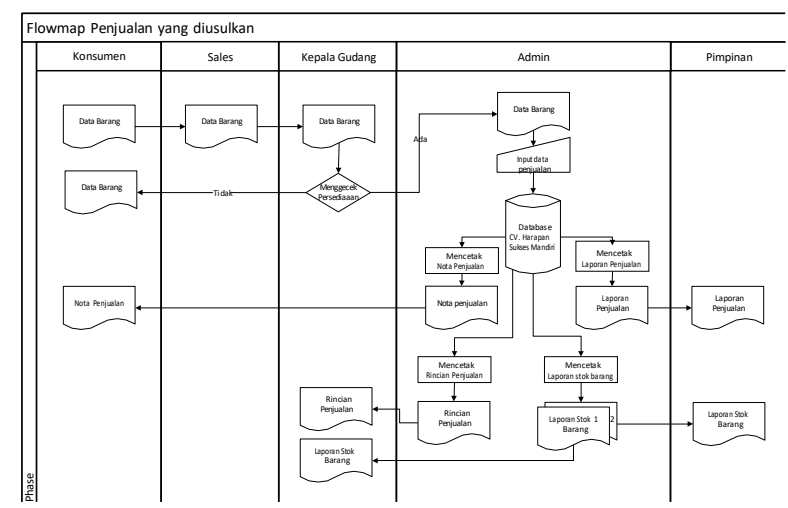

Gambar 5. Flowmap Penjualan yang diusulkan

\section{3) Data Flow Diagram}

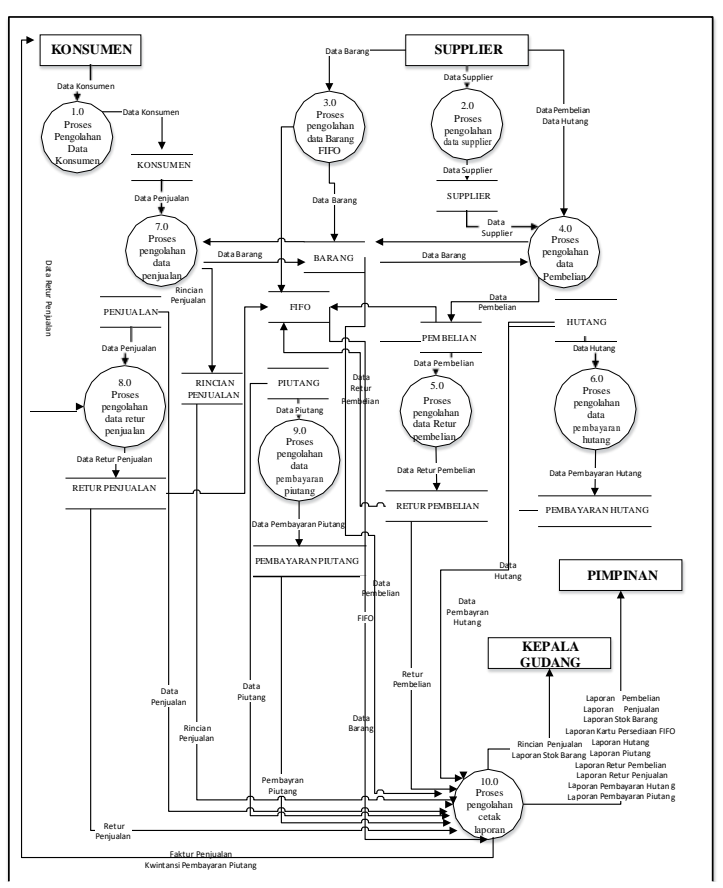

Gambar 6. Data Flow Diagram Sistem Informasi Persediaan barang dengan menggunakan metode perhitungan perpetual dan metode FIFO

\section{KESIMPULAN}

Setelah Pembuatan perancangan Sistem Informasi Persediaan Barang dengan menggunakan Metode Perhitungan Perpetual dan Metode First In First Out (FIFO) pada CV. Harapan Sukses Mandiri, Tanjungpinang ini bertujuan untuk mempermudahkan bagian kepala gudang dalam menghitung stok yang ada pada perusahaan dan mempermudahkan bagian admin dalam menyusun dan mencari laporan.

Perancangan Sistem Informasi Persediaan barang ini mampu untuk memberikan efektif kerja. berdasarkan hasil perancangan dan pembuatan sistem informasi persediaan barang ini yang telah dilakukan dapat disimpulkan hal-hal sebagai berikut, Mempermudahkan dalam proses pencarian dan pengolahan data transaksi jual-beli yang terjadi pada CV. Harapan Sukses Mandiri karena sudah menggunakan sistem terkomputerisasi, Meminimaliskan terjadinya kesalahaan atau kekeliruan dalam proses pencatatan persediaan barang., Akan lebih menghematkan waktu dalam pencarian laporan untuk menentukan jumlah stok barang, Dengan menggunakan sistem ini maka, bagian admin dapat dengan cepat mencari data transaksi sisa hutang/piutang yang harus dilunasin dan Setelah menggunakan sistem ini dapat menghematkan banyak waktu pada bagian admin dalam pencarian laporan per periode. 


\section{UCAPAN TERIMA KASIH}

Dalam kesempatan ini penulis ingin mengucapkan terimakasih kepada semua pihak yang telah membantu dalam menyelesaikan Skripsi ini dan secara khusus penulis sampaikan kepada, Ibu Dwi Nurul Huda, ST sebagai dosen pembimbing yang telah memberikan kontribusi yang berarti sehingga terselesainya jurnal ini, Bapak HM. Louis Frederik, S.E., S.H., M.M., C.MA selaku Ketua Sekolah Tinggi Teknologi Indonesia, Bapak Mochammad Rizki Romdoni, S.Kom, M.T selaku Ketua Program Studi Sistem Informasi, Bapak JangHua selaku pemilik CV. Harapan Sukses Mandiri yang telah mengizinkan penulis, Teman-teman yang telah memberi semangat dan masukan yang cukup berarti..

\section{REFERENSI}

[1] O’Brein, James A; Marakas, George M. Pengantar Sistem Informasi, Salemba Empat, Jakarta, 2017

[2] Nugroho, Adi, 2005, Analisis dan Perancangan Sistem Informasi dengan Metodologi Berorientasi Objek, Informatika Bandung.

[3] H. Sri Sulistyanto, Manajemen Laba teori dan model empiris , Yogyakarta, 2011.

[4] Yayah, Pudin Shatu, Kuasai Detail Akuntansi Perkantoran , Jakarta, 2016.

[5] Mulyadi, Bahan Ajar Sistem Informasi Manajeman, Jakarta, 2001.

[6] Hanif Al Fatta, Analisis dan perancangan Sistem Informasi untuk Keunggulan Bersaing Perusahaan \& Organisasi Modern, 2007.

[7] Dr.Deni Darmawan.S.Pd.,Sistem Informasi Manajemen, Bandung, 2004. 